\title{
Potensi Chlorella vulgaris Beijerinck Dalam Remediasi Logam Berat Cd Dan Pb Skala Laboratorium.
}

\author{
Florensia Setyaningsih Purnamawati ${ }^{1}$, Tri Retnaningsih Soeprobowati ${ }^{2}$, Munifatul Izzati $^{3}$ \\ ${ }^{1}$ Magister Biologi, Fakultas Sains dan Matematika, Undip \\ 2,3 Jurusan Biologi, Fakultas Sains dan Matematika, Undip \\ Jl. Prof Soedharto, Tembalang, Semarang - 50275 \\ Telepon (024) 7474754; Fax. (024) 76480690
}

\begin{abstract}
Abstrak
Salah satu dampak negatif modernisasi dan industrialisasi adalah pencemaran lingkungan. Perairan merupakan salah satu lingkungan yang paling terbebani bahan pencemar karena banyaknya limbah rumah tangga maupun industri yang akhirnya masuk ke lingkungan perairan. Salah satu bahan pencemar perairan yang paling membahayakan adalah logam berat karena bersifat non-biodegradable. Oleh karena itu perlu upaya penanganan maupun pencegahan terhadap bahan pencemar tersebut. Pengolahan limbah secara fisiko-kimiawi dinilai mahal, menurunkan biodiversitas, banyak lumpur yang dihasilkan, dan kurang efektif pada konsentrasi logam di bawah 50 $\mathrm{mg} / \mathrm{l}$. Bioremediasi merupakan salah satu metode perbaikan lingkungan yang lebih ramah lingkungan karena menggunakan agen hayati seperti bakteri, jamur, protista, dan tanaman. Chlorella vulgaris Beijerinck merupakan mikroalga bersel satu yang banyak tumbuh di perairan tawar dan laut, telah dimanfaatkan masyarakat sebagai bahan pakan, suplemen, biofuel dan bioremediasi. Penelitian ini bertujuan untuk menguji potensi $C$. vulgaris sebagai agen bioremediasi terhadap cemaran logam berat $\mathrm{Cd}$ dan $\mathrm{Pb}$ skala laboratorium. Penelitian menggunakan Rancangan Acak Lengkap (RAL). C. vulgaris ditumbuhkan dalam media kultur yang telah diberi pupuk Walne selama 76 hari. Media kultur ditambah ion logam $\mathrm{Cd}$ dan Pb dengan 3 konsentrasi yang berbeda yaitu 1 ppm, 3 ppm, dan 5 ppm, masing-masing 3 kali ulangan. Medium kultur tanpa penambahan logam dianggap sebagai kontrol. Kandungan logam berat dalam medium dan dalam sel $C$. vulgaris diukur dengan AAS. Hal yang diamati dalam penelitian ini adalah pola pertumbuhan populasi $C$. vulgaris, persentase penurunan logam $\mathrm{Cd}$ dan $\mathrm{Pb}$ oleh $C$. vulgaris, besarnya akumulasi logam dalam C. vulgaris, serta nilai Bioconcentration Factor (BCF). Berdasarkan penelitian tersebut terbukti bahwa $C$. vulgaris terbukti mampu menurunkan konsentrasi ion $\mathrm{Cd}$ dan $\mathrm{Pb}$ dalam perairan. Prosentase penurunan konsentrasi ion $\mathrm{Pb}$ dalam media kontrol, 1 ppm, 3 ppm, dan 5 ppm berturut-turut 70\%, 80\%, 62\%, dan $52 \%$ sedangkan dalam media Cd pada konsentrasi serupa berturut-turut 67\%, 79\%, 56\%, dan 51\%. C. vulgaris mampu mengakumulasi $\mathrm{Cd}$ lebih besar daripada $\mathrm{Pb}$. Berdasarkan nilai $\mathrm{BCF}$ terhadap $\mathrm{Cd}$ maupun $\mathrm{Pb}, C$. vulgaris tergolong akumulator logam.
\end{abstract}

Kata kunci : logam berat, bioremediasi, Chlorella vulgaris, bioakumulasi.

\section{PENDAHULUAN}

Pengembangan metode pengolahan limbah yang lebih efektif, efisien, dan ramah lingkungan terus diupayakan seiring meningkatnya kesadaran masyarakat untuk memperbaiki kualitas lingkungan. Penggunaan agen hayati untuk memperbaiki kualitas lingkungan yang tercemar, atau bioremediasi, dewasa ini dikembangkan untuk mengatasi masalah pencemaran tersebut. Bioremediasi mulai diterapkan untuk mengatasi pencemaran oleh limbah berbahaya, termasuk senyawa-senyawa logam berat. Berbagai jenis agen hayati seperti tumbuhan dan mikrobia (alga, jamur, serta bakteri) dapat digunakan sebagai adsorben alternatif untuk penyerapan ion logam dalam air limbah.

Bioremediasi menggunakan mikroalga banyak digunakan untuk mengatasi pencemaran limbah di perairan karena ketersediaannya yang banyak di perairan, cepat reproduksinya, rentang toksisitas mikroalga yang lebar, banyak limbah yang dapat diremediasi, dan bersifat non patogen. Mikroalga menggunakan limbah sebagai sumber nutrisi dan pendegradasi polutan secara enzimatis. Nitrogen dan fosfor yang terkandung dalam limbah tersebut digunakan sebagai sumber karbonnya (Muthukumaran et al., 2005; Olguin, 2003). Mikroalga mampu menurunkan konsentrasi 
logam dari medium biasanya melalui biosorpsi, adsorpsi dan bioakumulasi (Gin et.al., 2002; Boswell et.al., 2002; Rehman and Shakoori, 2003; Davis et.al., 2003; Chojnacka et.al., 2004). Beberapa mikroalga seperti Scenedesmus, Synechoccystis, Gleocapsa, Chroococcus, Anabaena, Lyngbya, Oscillatoria, dan Spirulina telah digunakan sebagai agen bioremediasi.

Logam berat merupakan salah satu komponen pencemar perairan yang cukup mendapat perhatian saat ini. Beberapa jenis logam berat berguna untuk metabolisme makhluk hidup dalam kadar rendah namun tidak demikian dalam kadar tinggi. Kadar logam berat yang tinggi bersifat toksik dan berbahaya bagi makhluk hidup. Logam berat sukar terdegradasi bahkan cenderung terakumulasi dalam tubuh makhluk hidup yang terpapar.

Logam berat menjadi polutan di udara, tanah dan perairan. Logam berat di udara berasal dari hasil pembakaran. Logam berat di tanah berasal dari hasil kegiatan antropogenik yang menggunakan bahan-bahan kimia seperti pupuk, pestisida, dan sebagainya. Kehadiran logam berat di perairan berasal dari buangan limbah rumah tangga, serapan air tanah, dan limbah industri. Penggunaan pupuk dan pestisida yang mengandung logam berat secara berlebihan serta lumpur-lumpur hasil pengolahan limbah industri meningkatkan kandungan logam berat di perairan. Logam berat yang telah teridentifikasi sebagai polutan dalam badan air antara lain adalah arsenik (Ar), copper $(\mathrm{Cu})$, kadmium $(\mathrm{Cd})$, timbal $(\mathrm{Pb})$, kromium $(\mathrm{Cr})$, nikel $(\mathrm{Ni})$, merkuri $(\mathrm{Hg})$, dan seng (Zn). Kurang lebih 20 jenis logam dikelompokkan sebagai senyawa toksik dalam konsentrasi tinggi dan berbahaya bagi kesehatan manusia (Akpor \& Muchie, 2010).

Namun tidak semua jenis limbah logam berat ditemukan di setiap industri. Dalam lampiran PP MenLH no. 1 th 2010, beberapa jenis logam berat dianggap sebagai bahan pencemar di berbagai jenis industri yang berbeda, misalnya $\mathrm{Cu}$, $\mathrm{Cd}, \mathrm{Ni}, \mathrm{Cr}$, dan $\mathrm{Zn}$ ditemukan dalam limbah industri lapis logam. Pada limbah industri soda kaustik ditemukan logam berat jenis $\mathrm{Cu}$ dan $\mathrm{Zn}$, selain $\mathrm{Hg}$ dan $\mathrm{Pb}$. Pada limbah industri baterai kering terdapat $\mathrm{Hg}, \mathrm{Zn}, \mathrm{Cr}, \mathrm{Ni}$, dan mangan $(\mathrm{Mn})$. Industri cat menghasilkan limbah jenis $\mathrm{Hg}, \mathrm{Zn}, \mathrm{Cu}$,
Cd dan Cr. Logam berat tersebut ada di lingkungan dengan konsentrasi yang berbeda-beda sehingga dapat digunakan sebagai petunjuk tingkat pencemaran suatu lingkungan. Pemerintah telah menentukan batas baku mutu lingkungan dengan beberapa peraturan. Berdasarkan PP MenLH 3/2010, nilai maksimal yang diijinkan sebagai ukuran baku mutu air limbah bagi kawasan Industri: Cd sebesar 0,1 mg/l; $\mathrm{Cu} 2 \mathrm{mg} / \mathrm{l} ; \mathrm{Pb} 1$ $\mathrm{mg} / \mathrm{l} ; \mathrm{Ni} 0,5 \mathrm{mg} / \mathrm{l} ; \mathrm{Zn} 10 \mathrm{mg} / \mathrm{l}$.

Logam berat $\mathrm{Cd}$ dan $\mathrm{Pb}$ merupakan 2 jenis logam yang kadar toksisitasnya cukup tinggi dan non-biodegradable. Kedua logam ini dipilih karena sering digunakan secara luas dalam proses komersial, industri logam, industri cat, tekstil, keramik, dan baterai (Kadirvelu et.al., 2001). Logam berat $\mathrm{Pb}$ dan $\mathrm{Cd}$ termasuk logam transisi yang dalam perairan ditemui dalam bentuk ion-ion bebas, pasangan ion organik, dan ion kompleks. Kedua logam ini belum diketahui manfaatnya bagi tubuh organisme, sebaliknya justru menimbulkan penyakit (Darmono, 1995).

Logam Cd, merupakan logam anorganik yang lebih toksik dibanding $\mathrm{Pb}$. Logam berat $\mathrm{Cd}$ seringkali digunakan dalam industri logam, batere, bahan cat warna, plastik, percetakan dan tekstil atau kegiatan pertanian yang mengakibatkan penumpukan $\mathrm{Cd}$ pada sedimen dan lumpur. Konsentrasi logam berat di laut meningkat karena adanya masukan dari daratan secara terus menerus (Sanusi, 2006). Keracunan $\mathrm{Cd}$ menyebabkan gangguan tubuh yang akut dan kronis seperti penyakit Itai-itai, kerusakan ginjal, emfisema, hipertensi, atropi testis (Leyva et.al., 1997), kerusakan paru-paru dan hati (Bedoui et.al.,2008) serta bersifat karsinogenik (Brown et.al., 2000).

Timbal $(\mathrm{Pb})$ dalam perairan dapat berasal dari kontaminasi pipa, solder, dan kran air, serta dari limbah industri yang dibuang ke sungai. Jenis industri yang menggunakan timbal dalam prosesnya antara lain industri pengolahan logam, kertas, batere, elektronik, dan sebagainya. Keracunan timbal berdampak pada gangguan sistem syaraf, sistem sirkulasi, ginjal dan sistem reproduksi (Tunali et.al., 2006).

Mengingat tingginya resiko cemaran logam $\mathrm{Pb}$ dan $\mathrm{Cd}$ terhadap kesehatan tubuh manusia dan biota yang lain, maka konsentrasinya dalam perairan perlu diupayakan agar tidak melebihi 
ambang batas baku mutu air. Industri harus melakukan pengolahan air limbah, sehingga ketika air limbah dibuang ke perairan umum tidak lagi membahayakan makhluk hidup. Namun, kendala utama dari pengolahan limbah adalah tingginya biaya pengolahan sehingga banyak industri yang tidak optimal melakukan pengolahan limbah buangan pabriknya.

Upaya yang biasa dilakukan oleh industri untuk mengatasi pencemaran logam berat pada umumnya secara fisiko-kimiawi (misalnya : elektrolisa, elektrodialisa, pengendapan) (Fardias, 1992). Kelemahan pengolahan cara ini masih menimbulkan masalah di akhir pengolahan, selain menurunkan biodiversitas, menghasilkan lumpur yang cukup banyak, berbiaya mahal dan tidak effektif terutama bila konsentrasi logam berat dalam perairan dibawah $50 \mathrm{mg} / \mathrm{l}$ ( Das et.al., 2008).

Chlorella vulgaris Beijerinck dimanfaatkan secara komersial karena tingginya nilai gizi yang dimiliki. Mikroalga ini mengandung protein, karbohidrat, lemak, vitamin, mineral, asam amino esensial, asam lemak esensial, enzim, beta karoten dan klorofil sehingga banyak digunakan sebagai pakan ikan, suplemen makanan, bahan penawar berbagai penyakit, bahan untuk biofuel dan bioremediator ( Srihati dan Carolina, 1994; Lim, et.al., 2010; Phukan et.al., 2011). Mikroalga uniseluler ini berbentuk simpel, fotosintetik, sehingga banyak dikembangkan dalam pengolahan limbah. Mikroalga ini mudah diperoleh di tempattempat pembudidayaan sumber daya laut meskipun secara alami juga banyak terdapat di perairan.

Chlorella sp. mampu menurunkan konsentrasi logam Cd secara maksimal sebesar $30,61 \%$ pada perlakuan $1,5702 \mathrm{ppm}$ pada skala laboratorium dengan menguji konsentrasi logam berat $\mathrm{Cd}$ air media di awal dan di akhir penelitian (Kusrinah, 2001). Penelitian Syahputra (2008) mendapatkan bahwa Chlorella pyrenidosa sebanyak $800 \quad \mathrm{ml} / \mathrm{l}$ memiliki efektifitas menurunkan kadar $\mathrm{Cu}$ sebesar $0,29 \mathrm{mg} / \mathrm{l}$ dengan efisiensi penurunan mencapai $90,97 \%$. Selanjutnya sel akan menyerap unsur logam tersebut sampai pada titik optimal, yang penyerapan ini dilakukan selama 7 hari. Namun $C$. pyrenoidosa punya keterbatasan yaitu tidak bisa bekerja pada suasana basa atau $\mathrm{pH}$ di atas 7. Kadar pencemar yang terlalu tinggi menyebabkan algae ini mati. Kematian alga terjadi pada kadar logam maksimal, seperti $\mathrm{Cu}$ maksimal $18 \mathrm{mg} / \mathrm{l}$, sedang $\mathrm{Cd}$, $\mathrm{Cr}$ dan Zn maksimal $10 \mathrm{mg} / \mathrm{l}$. C.vulgaris dalam penelitian Dominic, et.al. (2009) cukup efisien dalam memperbaiki kualitas air limbah industri yang terpolusi. Hasil penelitian menunjukkan bahwa C.vulgaris terbukti meningkatkan kadar $\mathrm{pH}$ limbah ke arah alkali (6-8) dibandingkan dua species lainnya, Gleocapsa gelatinosa dan Synechosistis salina. C. vulgaris menurunkan kandungan fosfat $69,23 \%$, dan nitrat sebesar $84 \%$. Dalam 5 hari, $52,8 \%$ nitrat terabsorpsi, sedangkan nitrit diserap $100 \%$. Kenaikan nilai DO oleh C. vulgaris juga paling tinggi yaitu sebesar $247,83 \%$. Strain Chlorella yang toleran terhadap logam mensekresikan material organik yang memicu penurunan konsentrasi ion logam bebas dalam medium (Prasad et.al., 2004 dalam Rehman and Shakoori, 2004). Pada penelitian Afkar et.al. (2010), C.vulgaris mampu mengakumulasi logam $\mathrm{Cu}^{2+}>\mathrm{Co}^{2+}>\mathrm{Zn}^{2+}$.

C.vulgaris laut dalam penelitian ini diteliti kemampuannya menurunkan konsentrasi logam berat $\mathrm{Pb}$ dan $\mathrm{Cd}$ dalam media kultur skala laboratorium dan akumulasinya dalam sel $C$. vulgaris.

\section{BAHAN DAN METODE \\ Tempat dan waktu penelitian}

Penelitian ini merupakan penelitian skala laboratorium, dilakukan di Laboratorium Ekologi dan Biosistematik, Jurusan Biologi Fakultas Sains dan Matematika UNDIP, bulan Juni - Oktober 2012.

\section{Sterilisasi Alat dan Media Kultur}

Sterilisasi bertujuan menghilangkan atau meminimalkan keberadaan mikroorganisme atau zat pengganggu pada alat dan media kultur yang akan digunakan selama penelitian. Tahapan sterilisasi yang dilakukan merujuk pada Isnansetyo dan Kurniastuty (1995) sbb :

a. Semua peralatan non elektronik dicuci dengan menggunakan sabun pencuci perabotan gelas, kemudian dibilas dengan air dingin yang telah dididihkan pada suhu $100^{\circ} \mathrm{C}$ sebelumnya. Kemudian peralatan dibilas dengan larutan $\mathrm{HCl}$ $4 \mathrm{~N}$ yang telah diencerkan $10 \%$ dan dibilas 
kembali dengan air dingin hasil rebusan. Selanjutnya dibilas dengan larutan alkohol $70 \%$ dan terakhir dibilas dengan aquades hingga hilang bau alkoholnya. Peralatan ditiriskan di atas meja yang telah disemprot alkohol sebelumnya.

b. Selang plastik aerator, gelas kultur, dan pengatur debit udara disterilkan terlebih dahulu dengan direndam larutan kaporit 10-15 menit. Kemudian dicuci dengan air dingin hasil rebusan dan ditiriskan seperti peralatan gelas.

\section{Penyiapan Media Kultur.}

Air laut disterilisasi dengan merebus hingga mendidih selama kurang lebih 2 jam, didinginkan sampai temparatur ruang. Air laut steril 11 dimasukkan dalam bejana kaca volume $3 \quad 1$ kemudian ditambahkan pupuk Walne 0,5 ml sebagai nutrisi bagi mikroalga. Bibit $C$. vulgaris dimasukkan ke dalam bejana tersebut kurang lebih $10.000 \mathrm{sel} / \mathrm{ml}$. Bibit tersebut diperoleh dari Laboratorium Balai Besar Pengembangan Budidaya Air Payau (BBPBAP) Jepara. Guna memperoleh kepadatan awal tersebut digunakan rumus yang digunakan Kusrinah (2001) :

$$
\begin{aligned}
\quad \mathrm{V}_{1} \mathrm{~N}_{1}=\mathrm{V}_{2} \mathrm{~N}_{2} \\
\mathrm{~V}_{1}=\text { volume inokulum yang diinginkan } \\
\mathrm{V}_{2}=\text { volume medium kultur } \\
\mathrm{N}_{1}=\text { kepadatan stok }(\mathrm{sel} / \mathrm{ml}) \\
\mathrm{N}_{2}=\text { kepadatan sel yang diinginkan }
\end{aligned}
$$

Medium kultur berada pada rentang $\mathrm{pH}$ optimum untuk produktivitas perairan, yaitu 7,5 8,5 (Basmi et al., 2004 dalam Prabowo, 2009). Salinitas medium berada pada konsentrasi tinggi, yaitu 34 ppt untuk menciptakan kondisi stress yang mampu mempercepat pertumbuhan mikroalga (Bosma dan Wijffels, 2003 dalam Prabowo, 2009). Sumber cahaya berasal dari cahaya lampu neon 36 watt dan temparatur kultur dapat berada pada rentang $27-28{ }^{\circ} \mathrm{C}$. Delapan belas bejana kultur disusun pada rak. Kemudian media kultur diukur kandungan logam $\mathrm{Pb}$ dan $\mathrm{Cd}$ total dengan AAS demikian juga kandungan kedua logam tersebut dalam sel C. vulgaris

Pada hari ke- 4, dalam kultur ditambahkan larutan logam $\mathrm{CdSO}_{4}$ dengan konsentrasi $1 ; 3 ; 5$ $\mathrm{mg} / \mathrm{l}(\mathrm{ppm})$ masing-masing 3 kali ulangan. Bejana kultur yang lain diisi dengan larutan logam
$\mathrm{Pb}\left(\mathrm{NO}_{3}\right)_{2}$ dengan 3 konsentrasi yang sama masing-masing 3 kali ulangan. Sebagai kontrol digunakan bejana kultur yang dibiarkan tanpa campuran logam berat. Faktor eksternal : intensitas cahaya, salinitas , $\mathrm{pH}$ dan suhu dipantau selalu dalam keadaan yang relatif konstan setiap harinya. Jumlah sel Chlorella vulgaris dihitung setiap harinya dengan rentang waktu 24 jam hingga 76 hari penelitian menggunakan Haemocytometer Neubauer Improved (Isnansetyo dan Kurniastuty, 1995) dengan 2 kali pengukuran untuk masingmasing kultur. Jumlah sel yang diamati dan dihitung pada kotak bujur sangkar yang mempunyai sisi $1 \mathrm{~mm}$. Rumus yang digunakan : Kepadatan $=\mathrm{N} \mathrm{x} 10^{4} \mathrm{sel} / \mathrm{ml}$

( $\mathrm{N}=$ jumlah Chlorella vulgaris yang diamati)

\section{Pengamatan Penelitian}

Parameter yang diamati meliputi :

1. Kandungan logam berat $\mathrm{Cd}^{2+}$ dan $\mathrm{Pb}^{2+}$ dalam medium kultur hari ke-0 dan hari ke-76.

2. Kandungan logam berat total $\mathrm{Cd}^{2+}$ dan $\mathrm{Pb}^{2+}$ dalam C.vulgaris hari ke-0 dan hari ke-76.

Persentase penurunan konsentrasi logam berat $\mathrm{Pb}$ dan Cd dengan rumus :

a. Penurunan konsentrasi logam berat = Konsentrasi logam berat awal konsentrasi logam berat akhir

b. Prosentase penurunan konsentrasi = (Penurunan konsentrasi logam berat / konsentrasi logam awal) x $100 \%$

Faktor biokonsentrasi (Bioconcetration Factor /BCF) merupakan koefisien untuk mengelompokkan efisiensi akumulasi elemen toksik dalam biota dan mediumnya. Menurut Zayed et.al., 1998 dalam Sekabira et.al. (2011) rumus $\mathrm{BCF}$ :

$$
\mathrm{BCF}=\mathrm{Cb} / \mathrm{Cw}
$$

$\mathrm{Cb}:$ konsentrasi logam berat dalam biota

$\mathrm{Cw}$ : konsentrasi logam berat dalam medium

Nilai $\mathrm{BCF}<1$ : exluder; > 1 : akumulator logam; dan $\geq 1000$ : akumulator logam yang baik (good acumulator)

\section{HASIL DAN PEMBAHASAN}

Kemampuan $C$. vulgaris dalam Penurunan Konsentrasi Logam

Kemampuan sel $C$. vulgaris dalam menurunkan kandungan logam berat sangat 
dipengaruhi oleh faktor lingkungan baik biotik dan abiotik. Faktor lingkungan biotik meliputi sifat karakteristik mikrobia dan kepadatan sel, sedangkan faktor abiotik meliputi $\mathrm{pH}$, kandungan nutrien, temparatur dan cahaya (Malick dan Rai, 1993).

Berdasarkan uji kandungan ion logam berat $\mathrm{Cd}$ dan $\mathrm{Pb}$ dalam medium pada awal perlakuan dan akhir perlakuan penelitian ini menunjukkan terjadinya pengurangan konsentrasi ion logam baik $\mathrm{Pb}$ maupun $\mathrm{Cd}$. Sel C. vulgaris telah melakukan biosorpsi (Tabel 1). Pada setiap kelompok perlakuan dengan penambahan ion logam $\mathrm{Pb}$ menunjukkan penurunan konsentrasi ion logam di akhir penelitian. Dinding sel C. vulgaris mampu mengikat ion $\mathrm{Pb}$. Demikian pula yang terjadi pada kelompok dengan penambahan ion $\mathrm{Cd}$. Imani et.al. (2011) menyatakan bahwa faktor kunci remediasi logam adalah bahwa logam bersifat non-biodegradable tetapi dapat melakukan transformasi melalui proses sorpsi, metilasi, kompleksasi dan mengubah nilai valensinya. Saat ion logam berat tersebar di sekitar sel, ion logam akan terikat pada elemen yang terdapat pada dinding sel berdasarkan kemampuan daya affinitas kimia yang dimiliki sel tersebut (Droste, 2007).

Sebelum ion logam sampai ke membran sel dan sitoplasma sel, ion logam tersebut harus melalui dinding sel mikroalga yang mengandung berbagai macam variasi polisakarida dan protein yang memiliki sejumlah sisi aktif yang mampu berikatan dengan ion logam. Terjadi pertukaran ion monovalen dan divalen seperti $\mathrm{Na}, \mathrm{Mg}$, dan $\mathrm{Ca}$ yang terdapat pada dinding sel digantikan oleh ion-ion logam berat kemudian terbentuk formasi kompleks antara ion-ion logam berat dengan kelompok fungsional seperti karbonil, amino, thiol, hidroksi, fosfat dan hidroksi-karboksil. Proses biosorpsi ini berlangsung cepat dan bolak- balik dan terjadi baik pada sel mati maupun pada sel hidup. Proses ini berlangsung efektif dengan kehadiran $\mathrm{pH}$ tertentu dan kehadiran ion-ion lainnya dimana logam berat dapat menjadi garam tak terlarut yang diendapkan (Tortora, 2001 ; Glick and Pasternak, 2001). Maka dinding sel sering disebut sebagai bagian terpenting dari mekanisme pertahanan sel karena dinding sel merupakan penghalang pertama terhadap akumulasi logam berat yang bersifat toksik.

Pada penelitian ini ion-ion logam baik $\mathrm{Pb}$ maupun $\mathrm{Cd}$ yang bervalensi 2 akan menggantikan ion divalen ataupun monovalen yang terdapat pada dinding sel $C$. vulgaris sehingga ion logam di luar sel tentu akan berkurang. Di samping itu $\mathrm{pH}$ medium yang berkisar antara 7-8 masih memungkinkan terjadinya biosorpsi ini meskipun mungkin masih ada sebagian ion logam yang berikatan dengan ion lain sehingga menjadi garam yang terendapkan.

Dalam penelitian ini penurunan konsentrasi logam belum mencapai ambang baku mutu, yaitu $0,1 \mathrm{mg} / \mathrm{l}$ untuk $\mathrm{Cd}$ dan $1 \mathrm{mg} / \mathrm{l}$ untuk $\mathrm{Pb}$. Baik pada kultur dengan penambahan $3 \mathrm{ppm}$ dan $5 \mathrm{ppm} \mathrm{Pb}$ maupun penambahan ion $\mathrm{Cd}$ konsentrasi logam di akhir penelitian masih di atas ambang batas yang diijinkan. Hal ini mungkin karena konsentrasi ion logam yang ditambahkan sudah melebihi ambang batas atau karena jumlah sel $C$. vulgaris yang tidak mencukupi untuk terjadinya biosorpsi sehingga konsentrasi logam di akhir penelitian masih cukup tinggi. Kemungkinan yang lain karena lamanya perlakuan tanpa penambahan nutrisi maupun sel $C$. vulgaris. Pengujian kandungan logam di akhir perlakuan (76 hari) ketika populasi sel mengalami penurunan jumlah dan kualitas menyebabkan berkurangnya daya adsorbsi serta akumulasi logam. 
Tabel 1. Konsentrasi rata-rata ion logam $\mathrm{Pb}$ dan $\mathrm{Cd}$ dalam medium awal dan akhir perlakuan serta prosentase penurunan logam dalam medium

\begin{tabular}{|c|c|c|c|}
\hline \multirow{2}{*}{$\begin{array}{c}\text { Konsentrasi } \\
\text { logam } \\
(\mathrm{mg} / \mathrm{l})\end{array}$} & \multicolumn{2}{|c|}{$\begin{array}{c}\text { konsentrasi } \\
\text { dalam } \\
\text { medium } \\
(\mathrm{mg} / \mathrm{l})\end{array}$} & \multirow{2}{*}{$\begin{array}{c}\text { Rata-Rata } \\
\text { prosentase } \\
\text { Penurunan } \\
\text { Logam } \\
\text { Dalam } \\
\text { Medium } \\
(\%)\end{array}$} \\
\hline & HO & H76 & \\
\hline $\mathrm{Pb} 1$ & 1,01 & 0,20 & $80^{a}$ \\
\hline 3 & 3,01 & 1,13 & $62^{c}$ \\
\hline 5 & 5,01 & 2,39 & $52^{d}$ \\
\hline Kontrol & 0,010 & 0,003 & $70^{b}$ \\
\hline $\mathrm{Cd} 1$ & 1,009 & 0,21 & $79^{\mathrm{e}}$ \\
\hline 3 & 3,009 & 1,33 & $56^{\mathrm{f}}$ \\
\hline 5 & 5,009 & 2,45 & $51^{\mathrm{f}}$ \\
\hline kontrol & 0,009 & 0,003 & $67^{\mathrm{g}}$ \\
\hline
\end{tabular}

Huruf yang berbeda pada satu kolom menunjukkan perbedaan yangnyata

\section{Prosentase penurunan konsentrasi logam dalam medium}

Berdasarkan table 1, prosentase penurunan konsentrasi logam oleh $C$. vulgaris semakin menurun dengan meningkatnya konsentrasi logam yang dipaparkan dalam medium.

Pada Gambar 1 ditunjukkan bahwa besarnya penurunan konsentrasi logam $\mathrm{Pb}$ dari kelompok kontrol, 1 ppm, 3 ppm, 5 ppm berturutturut sebesar $70 \%, 80 \%, 62 \%, 52 \%$ yang artinya menunjukkan semakin tingginya konsentrasi logam yang ditambahkan prosentase penyerapan ion logam semakin rendah. Demikian juga pada kelompok perlakuan dengan penambahan ion $\mathrm{Cd}$, berturut-turut prosentase penyerapannya $67 \%$ untuk kelompok kontrol, 79\% untuk kelompok 1 ppm, 56\% untuk kelompok 3 ppm, dan 51\% untuk kelompok 5 ppm.

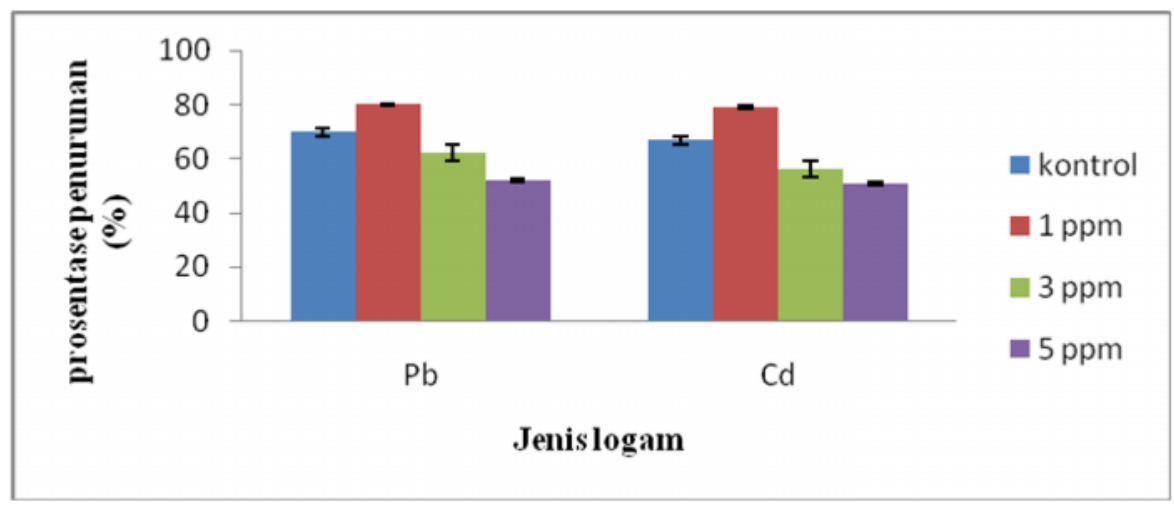

Gambar 1. Grafik Prosentase penurunan kandungan ion logam berat $\mathrm{Pb}$ dan $\mathrm{Cd}$ pada medium oleh C. vulgaris pada hari ke-76.

Hasil analisis ANOVA diketahui bahwa perbedaan konsentrasi menunjukkan beda nyata dalam prosentase penurunan ion logam $\mathrm{Pb}$ dan $\mathrm{Cd}$. Medium dengan penambahan konsentrasi 1 ppm paling banyak penurunannya dibanding medium dengan penambahan $3 \mathrm{ppm}$ serta $5 \mathrm{ppm}$.

Hal ini agak serupa dengan penelitian yang dilakukan oleh Chen dan Pan (2005) yang 
menyatakan bahwa konsentrasi ion $\mathrm{Pb}$ awal berpengaruh pada rata-rata adsorpsi logam tersebut oleh Spirulina sp. Ditemukan bahwa biosorpsi ion $\mathrm{Pb}$ meningkat sampai $95 \%$ pada medium yang berisi larutan ion $\mathrm{Pb}$ konsentrasi awal di bawah $10 \mathrm{mg} / \mathrm{l}$, sedangkan pada medium yang berisi ion $\mathrm{Pb}$ konsentrasi di atas $10 \mathrm{mg} / \mathrm{l}$ rata-rata biosorpsinya menurun.

$\mathrm{Pb}$ terlarut dapat membentuk ikatan ligand organik dalam tubuh fitoplankton. $\mathrm{Pb}$ dapat membentuk ikatan yang cukup kuat dengan ligand organik yang mengandung N,O,S yaitu gugusgugus rangkap yang terdapat dalam protein, lemak dan karbohidrat dan berperan sebagai donor atom (Darmono, 1995). Pada kondisi pH tinggi, potensial redoks akan rendah sehingga logamlogam akan lebih aktif membentuk kompleks dengan senyawa-senyawa organik dan dapat membentuk kelat yang lebih mudah larut dalam air.

Semakin lama Chlorella sp terpapar oleh logam maka prosentase penyerapan ion logam $\mathrm{Ni}^{2+}$ dan $\mathrm{Cd}^{2+}$ semakin tinggi. Setelah terpapar ion $\mathrm{Cd}^{2+} 5 \mu \mathrm{g} / \mathrm{ml}$ selama 7 hari , Chlorella mampu menyerap $76 \% \quad \mathrm{Cd}^{2+}$ dari medium, $80 \%$ setelah 14 hari, $88 \%$ setelah 21 hari dan $96 \%$ setelah 28 hari. Pada penelitian ini paparan ion logam selam 76 hari didapatkan prosentase penurunan kelompok $\mathrm{Pb} 80 \%, 62 \%, 52 \%$ dalam konsentrasi 1 ppm, 3 ppm, dan 5 ppm. Sedangkan kelompok Cd 1 ppm, 3 ppm, dan 5 ppm : 76\%, 56\%, 51\%. Tampak dalam penelitian ini besar prosentase penurunan logam $\mathrm{Pb}$ lebih besar dibandingkan besarnya prosentase penurunan $\mathrm{Cd}$. Besarnya penurunan konsentrasi logam dalam penelitian tentang bioremoval selalu berbeda-beda sesuai dengan metode yang digunakan dan kondisi lingkungan maupun mikroalga yang dimanfaatkan. Namun sebagian besar penelitian menyebutkan bahwa penurunan konsentrasi $\mathrm{Pb}$ seringkali lebih besar dibandingkan penurunan konsentrasi $\mathrm{Cd}$.
Seperti hasil penelitian Soeprobowati dan Haryati (2012) yang menunjukkan besarnya prosentase penurunan $\mathrm{Pb}$ oleh Chlorella $90 \%$ dengan populasi kurang dari $300 \times 10^{2}$ individu/ml sedangkan prosentase penurunan $\mathrm{Cd} 62 \%$ dengan populasi $350 \times 10^{2}$ individu/ml. Kemungkinan karena daya toksik ion $\mathrm{Cd}$ lebih kuat dibandingkan ion $\mathrm{Pb}$ sehingga kerusakan sisi adsorbsi dinding sel karena ion $\mathrm{Cd}$ lebih besar, akibatnya ion $\mathrm{Cd}$ tidak dapat teradsorbsi lebih banyak dibandingkan ion $\mathrm{Pb}$.

Gugus fungsi pada dinding sel seperti karboksil, tiol dan beberapa enzim yang mengandung $\mathrm{Zn}$ dapat berinteraksi dengan ion logam Cd melalui ikatan kovalen atau melalui pertukaran ion. Gugus $\mathrm{C}=\mathrm{O}$ dan $\mathrm{S}-\mathrm{H}$ merupakan basa lunak yang akan terikat kuat oleh ion logam Zn, sedangkan dalam setiap sel terdapat 260 jenis enzim yang membutuhkan ion logam $\mathrm{Zn}$ yang dapat digantikan oleh ion logam $\mathrm{Cd}$ sehingga dapat merusak kerja enzim dan mengganggu jaringan sel fitoplankton. (Liljas, 1972). Pada kadar 0,01-0,1 mg/l $\mathrm{CdCl}_{2}$ dapat mereduksi ATP, klorofil dan konsumsi $\mathrm{O}_{2}$ oleh fitoplankton (Sanusi, 2006).

Dengan demikian tingginya konsentrasi ion logam $\mathrm{Pb}$ dan $\mathrm{Cd}$ dalam medium berpengaruh terhadap besarnya penurunan ion logam. Chlorella vulgaris Beijerink mampu menurunkan ion logam $\mathrm{Pb}$ lebih baik dibandingkan kemampuannya menurunkan ion $\mathrm{Cd}$.

\section{Akumulasi logam dalam sel Chlorella vulgaris}

Setelah terjadi proses biosorpsi (passive uptake), mekanisme berikutnya adalah active uptake di mana sel C. vulgaris memindahkan ion logam yang telah terikat di dinding sel ke organel sel yang lebih dalam (bioakumulasi/absorpsi). Mekanisme ini terjadi sejalan dengan konsumsi ion logam untuk pertumbuhan sel dan akumulasi ion logam tersebut. 
Tabel 2. Konsentrasi Rata-Rata Ion Logam Pb dan Cd Dalam Sel C. vulgaris Awal Dan Akhir Perlakuan Serta Nilai $\mathrm{BCF}$

\begin{tabular}{cccr}
\hline \multirow{2}{*}{$\begin{array}{c}\text { Konsentrasi } \\
\text { logam } \\
(\mathbf{m g} / \mathbf{l})\end{array}$} & \multicolumn{3}{c}{$\begin{array}{l}\text { Konsentrasi dalam } \\
\text { sel Chlorella }(\mathbf{m g} / \mathbf{l})\end{array}$} \\
\cline { 2 - 4 } & $\mathbf{H 0}$ & $\mathbf{H 7 6}$ & $\mathbf{B C F}$ \\
\hline $\mathrm{Pb} 1$ & 0,02 & 2,15 & $10,75^{\mathrm{a}}$ \\
3 & 0,02 & 4,08 & $3,61^{\mathrm{b}}$ \\
5 & 0,02 & 6,02 & $2,51^{\mathrm{b}}$ \\
Kontrol & 0,02 & 0,034 & $11,33^{\mathrm{a}}$ \\
\hline $\mathrm{Cd} 1$ & 0,013 & 1,23 & $5,85^{\mathrm{c}}$ \\
3 & 0,013 & 2,78 & $2,09^{\mathrm{d}}$ \\
5 & 0,013 & 4,02 & $1,64^{\mathrm{d}}$ \\
kontrol & 0,013 & 0,016 & $5,33^{\mathrm{c}}$ \\
\hline
\end{tabular}

Huruf yang berbeda pada satu kolom menunjukkan perbedaan yang nyata

Berdasarkan tabel 2 nampak bahwa terjadi peningkatan konsentrasi ion logam $\mathrm{Pb}$ dan ion $\mathrm{Cd}$ dalam sel C. vulgaris dalam medium kultur di akhir penelitian. Berdasarkan hal tersebut maka dapat dinyatakan bahwa terjadi biokonsentrasi, yaitu peningkatan konsentrasi ion logam dalam biota yang nilainya lebih tinggi dibandingkan konsentrasi ion logam dalam medium. Apabila paparan bahan toksik berlangsung terus menerus sel akan mengalami bioakumulasi.

Fitoplankton dapat digunakan sebagai agen kelat bagi logam berat yang terlarut dalam badan air. Beberapa senyawa organik dalam tubuh fitoplankton, termasuk klorofil, mampu mengikat logam berat membentuk senyawa kompleks melalui gugus-gugus yang reaktif terhadap logam berat seperti sulfidril dan amina. Ikatan kompleks tersebut menyebabkan logam berat menjadi lebih stabil dan terakumulasi dalam sel fitoplankton. Namun kandungan senyawa organik yang berperan sebagai ligand tidak sama pada setiap jenis fitoplankton tergantung kondisi fisiologisnya. Melalui proses aktif Chlorella dapat mensintesis protein pengkelat logam. Fitokelatin disintesis dari turunan tripeptida (glutation) yang tersusun dari glutamat, cystin dan glisin. Glutation ini ada dalam seluruh sel. Jika terjadi pencemaran logam $\mathrm{Cd}$ misalnya glutation akan membentuk fitokelatin-Cd selanjutnya diteruskan ke vakuola (Haryoto dan Agustono, 2004). Penyerapan logam $\mathrm{Cd}$ berkaitan dengan $\mathrm{pH}$ medium :

$$
2 \mathrm{~S}-\mathrm{H}+\mathrm{Cd}^{2+} \quad \longleftrightarrow \mathrm{S}-\mathrm{Cd}-\mathrm{S}+2 \mathrm{H}^{+}
$$

$\mathrm{S}=$ permukaan absorben

(Dasta \& Tabati, 1992 dalam Haryoto \& Agustono, 2004)

Akumulasi Cd meningkatkan konsentrasi ion $\mathrm{H}^{+}$. Karena reaksi kesetimbangan maka kenaikan $\mathrm{pH}$ medium menyebabkan reaksi bergeser ke produksi ion $\mathrm{H}^{+}$yang artinya makin banyak jumlah logam Cd terkomplekskan.

Proses akumulasi ion logam ini cenderung menetap dalam sel karena harga konstanta laju pelepasan logam lebih kecil dibandingkan laju penyerapannya. Proses penyerapan dan akumulasi bahan toksik dalam sel akan dipecah dan diekskresikan, disimpan atau dimetabolisme oleh organisme tergantung konsentrasi dan potensial kimia bahan tersebut. Bahan kimia yang hidrofilik seperti $\mathrm{Pb}, \mathrm{Cd}, \mathrm{Hg}, \mathrm{Cu}$ dan Co biasanya lebih mudah diekskresikan dibandingkan logam yang bersifat lipofilik. Tetapi meskipun sifat logam tersebut hidrofilik dapat terikat erat pada tempattempat tertentu dari tubuh dan terakumulasi.

Chlorella pyrenidosa lebih banyak mengakumulasi ion $\mathrm{Cd}^{2+}$ pada $\mathrm{pH} 7$ dibandingkan pada $\mathrm{pH}$ 8. Pada $\mathrm{pH}$ basa ion logam secara spontan akan bereaksi dengan ion hidroksida membentuk ikatan logam-hidroksida membentuk ikatan logamhidroksida, sedangkan pada $\mathrm{pH}$ asam akan terjadi persaingan antara ion logam dengan ion $\mathrm{H}^{+}$untuk berikatan dengan dinding sel mikrobia. Sehingga akumulasi logam dalam sel mikrobia pada $\mathrm{pH}$ netral lebih besar dibanding dengan $\mathrm{pH}$ asam maupun basa. 
Berdasarkan hal di atas maka $C$. vulgaris mampu mengakumulasi ion logam $\mathrm{Pb}$ dan $\mathrm{Cd}$ dengan konsentrasi yang bervariasi dalam jangka waktu yang lebih lama dan bersifat menetap. Penambahan ion $\mathrm{Pb} 1 \mathrm{ppm}, 3$ ppm, dan 5 ppm ke dalam medium, menunjukkan nilai biokonsentrasi yang semakin rendah dalam $C$. vulgaris. Demikian juga pada penambahan ion $\mathrm{Cd}$ terjadi akumulasi ion logam pada $C$. vulgaris yang nilainya semakin menurun seiring dengan peningkatan konsentrasi ion logam yang ditambahkan. Kecuali pada kelompok kontrol Cd, yang nilai biokonsentrasinya lebih rendah dibandingkan kelompok perlakuan.

Pada penelitian yang dilakukan oleh Imani et.al. (2011) menyatakan bahwa peningkatan konsentrasi ion $\mathrm{Pb}, \mathrm{Cd}$ dan $\mathrm{Hg}$ menghambat pertumbuhan sel Dunaliella. Namun Dunaliella merupakan salah satu alga yang cukup toleran dengan konsentrasi ion logam $\mathrm{Pb}, \mathrm{Cd}$ dan $\mathrm{Hg}$ yang tinggi hingga $40 \mathrm{mg} / \mathrm{l}$. Dunaliella mampu mengabsorpsi $\mathrm{Pb}, \mathrm{Cd}$ dan $\mathrm{Hg} 65 \%, 72 \%$ dan $65 \%$ hingga 1 jam kontak. Setelah itu terjadi proses absorbsi yang konstan sampai 40 jam pada setiap eksperimen (Faryal and Hameed, 2005; Faryal et.al., 2006; Fomina et.al., 2005).

Jumlah dan macam nutrien yang terdapat di lingkungan mempengaruhi aktivitas mikrobia untuk mengatasi limbah logam berat. Penambahan asam-asam organik dan logam valensi 2 dapat menghambat pengikatan logam berat $\mathrm{Ni}^{2+}$ dan $\mathrm{Cr}^{6+}$ oleh sel Chlorella vulgaris dan Anabaena doliolum (Mallick and Rai, 1993). Penambahan Fe-EDTA dan $\mathrm{FeCl}_{3}$ dan Mangan (0,2 mg/l) akan menghambat akumulasi kadmium dalam sel Chlorella pyrenidosa (Hart dan Scaife, 1997).
Jika bioakumulasi berlanjut maka dapat terjadi biomagnifikasi yang melibatkan rantai makanan sebagai penghubungnya. Biomagnifikasi merupakan kecenderungan peningkatan konsentrasi bahan pencemar seiring dengan peningkatan level tropik pada rantai makanan. Sehingga produsen mengakumulasi bahan toksik terendah dan konsumen terakhir mengakumulasi paling banyak. Meskipun pada beberapa penelitian tidak ditemukan biomagnifikasi pada rantai makanan di perairan laut. Hal ini karena logam mudah dieliminasi dan tidak terakumulasi bahkan di tingkat trofik di atas ikan biosorpsi logam menurun sesuai dengan peningkatan ukuran tubuh organisme (Gray, 2002). Tetapi mengingat besarnya logam yang tereliminasi lebih sedikit dibandingkan yang terakumulasi maka bioakumulasi ion logam dalam mikroalga, terutama $C$. vulgaris, perlu mendapat perhatian.

\section{Nilai BCF (Bioconcentration Factor)}

BCF merupakan koefisien untuk mengelompokkan efisiensi akumulasi elemen toksik dalam biota dan mediumnya. Berdasarkan rumus Zayed et.al. (1998) diketahui bahwa $C$. vulgaris merupakan akumulator logam $\mathrm{Pb}$ dan $\mathrm{Cd}$ karena nilai $\mathrm{BCF}>1$ (gambar 4.5). Berdasarkan uji ANOVA nilai BCF kelompok kontrol dan kelompok perlakuan 1 ppm pada medium $\mathrm{Pb}$ dan $\mathrm{Cd}$ tidak menunjukkan beda nyata meskipun nilai BCF kelompok tersebut lebih tinggi dibanding kelompok perlakuan $3 \mathrm{ppm}$ dan $5 \mathrm{ppm}$. Uji ANOVA untuk kelompok perlakuan 3 ppm dan 5 ppm pada kedua jenis logam juga menunjukkan tidak ada beda nyata 


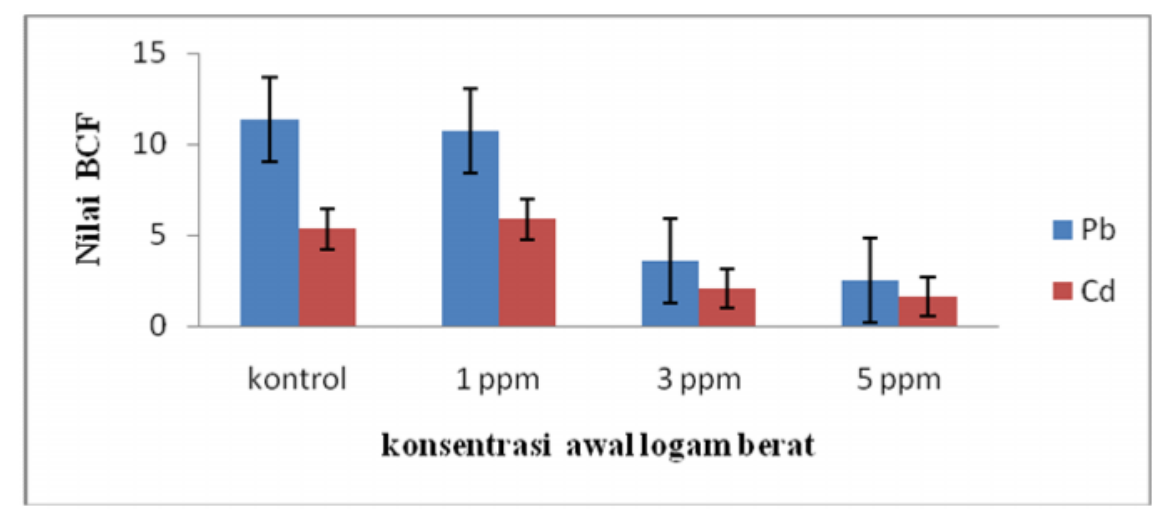

Gambar 2. Grafik Nilai BCF C. vulgaris

Perbedaan nilai BCF pada berbagai penelitian tergantung pada strain dan kondisi strain seperti sumber strain, usia kultur, $\mathrm{pH}$ dan waktu terpapar (Inthorn et al., 2002). C. vulgaris dalam penelitian ini merupakan kultur tunggal yang diperoleh dari BPAP Jepara yang kualitasnya cukup baik dan sering digunakan sebagai obyek penelitian. Strain ini merupakan strain yang sangat toleran dengan bahan pencemar bahkan dengan konsentrasi bahan pencemar yang tinggi. Usia kultur memang cukup lama 76 hari, namun ternyata $C$. vulgaris masih mampu tumbuh dan menyerap ion logam $\mathrm{Pb}$ dan $\mathrm{Cd}$ dengan kondisi nutrisi yang minim. Nilai $\mathrm{pH}$ medium di akhir penelitian yang ada pada level 8 belum cukup maksimal menyerap logam. Dengan demikian $C$. vulgaris layak digunakan sebagai agen biomonitoring logam $\mathrm{Pb}$ dan $\mathrm{Cd}$ perairan laut.

Penggunaan $C$. vulgaris hidup dalam proses remediasi perairan memang masih perlu ditingkatkan mengingat masih banyak kelemahan dalam proses ini. Penggunaan sel bebas ini cocok untuk kepentingan laboratorium tetapi untuk penggunaan di lapangan kurang aplikatif. Selnya yang relatif kecil, kekuatan mekanisnya yang rendah, tekanan hidostatik yang berlebihan mengurangi kemampuan sel untuk melakukan remediasi. Maka sistem ini perlu ditingkatkan mungkin dengan penambahan nutrisi dan sejumlah sel $C$. vulgaris pada fase stasioner. Pemanfaatan imobilisasi sel dengan menggunakan beberapa matriks dapat juga menjadi solusi yang baik namun berbiaya relatif lebih mahal. Imobilisasi sel dapat memuat lebih banyak biomassa, meminimalkan penyumbatan, lebih tahan tekanan, tidak butuh perawatan dan nutrisi, dapat digunakan berulang-ulang, bahkan kemungkinan mampu menurunkan konsentrasi bahan pencemar lebih besar

\section{DAFTAR PUSTAKA}

Afkar , E., H. Ababna dan A.A. Fathi. 2010. Toxicological Response of the Green Alga Chlorella vulgaris, to Some Heavy Metals. American Journal of Environmental Sciences 6 (3) : $230-237$

Akpor O.B and Muchie M. 2010. Remediation Of Heavy Metal In Drinking Water And Wastewater Treatment Systems : Processes And Applications. International Joernal of Physical Sciences vol. 5 (12) pp 1807-1817

http//: www.academicjournals.org/IJPS

Ariono, D., 1996. Bioremediasi Logam Berat di Lingkungan Perairan dengan Bantuan Mikroba. Jurnal Biota vol. I (2) : 23-27

Bedoui,K.., I.Bekri-Abbes, E.Srasra. 2008. Removal of Cadmium (II) from Aqueous Solution Using Pure Smectite and Lewatite S 100 : The Effect of Time and Metal Concentration, Desalination. 223, 269-273

Boswel,C., N. C. Sharma dan S.V. Sahi. 2002. Cooper Tolerance and Accumulation Potential of Chlamydomonas reinhardtii. Bull. Environ. Contam. Toxicol. 69: 546-553 Brown,P.A., S.A. Gill, S.J. Allen. 2000. Metal Removal from Wastewater Using Peat. Water Res. 34 :3907-3916. 
Chen dan S. Pan. 2005. Bioremediation potensial of Spirulina sp : Toxicity And Biosorption Studies Of Lead. Journal of Zhejiang University Science.

Chojnacka,K., A. Chojnacki dan H. Gorecka. 2004. Trace Element Removal by Spirulina sp. From Copper Smelter and Refinery Effluent. Hydrometallurgy, 73 : 147-153

Darmono. 1995. Logam dalam Sistem Biologi Makhluk Hidup. Universitas Indonesia Press. Jakarta

Das, N., R. Vimala, and P. Karthika. 2008. Biosorption of Heavy Metals-An Overview. Indian Journal of Biotechnology vol. 7, pp 159-169.

Davis, T.A., B. Volesky dan A. Mucci. 2003. A Review of The Biochemistry of Heavy Metal Biosorption by Brown Algae. Water Res., 37 : 4311- 4330

Dominic VJ, S. Murali and MC Nisha. 2009. Phycoremediation Efficiency Of Three Micro Algae Chlorella vulgaris, Synechocystis salina and Gloeocapsa gelatinosa. SB Academic Review Vol. XVI: No.1 \& 2 :138-146

Droste, R. 2007. Theory and Practice of Water and Wastewater Treatment. John Wiley and Sons. New York. USA.

Fardiaz, S. 1992. Polusi Air dan Udara. Kanisius. Yogyakarta. 190 hal

Faryal, R., A. Hameed. 2005. Isolation and Characterization of Various Fungal Strains from Textile Effluent for Their Use in Bioremediation. Pak. J. Bot., 37 : 10031008

Faryal, R., A. Lodhi, A. Hameed. 2006. Isolation, Characterization and Biosorption of Zinc by Indigenous Fungal Strains aspergillus fumigatus RH05 and Aspergillus flavus RH07. Pak. J. Bot., 38 : 817 - 831

Fomina, M., S. Hiller, JM Charnock, K Melvillie, IJ Alexander, GM Gadd. 2005. Role of Oxalic Acid Over-Excretion in Toxic Metal Mineral Transformations by Beauveria caledonica. Appl. Environ. Microbiol., 7 (1) : 371 - 381

Gin, K.Y., Y.Z. Tang dan M.A. azis. 2002. Derivation and Application of a New Model for Heavy Metal Biosorption by algae. Water Res., 36 : 1313 - 1323

Glick, Bernard and Pasternak. 2001. Molecular Biotechnology. ASM Press. Washington DC. USA

Gray,J.S. 2002. Biomagnification in Marine System : The Perpective of an Ecologist. Marine Pollution Bulletin 45: 46-52. http://www.elsevier.com/locate/morpolbud

Hart,B.A., and B.D. Scafie. 1997. Toxicity dan Bioacumulation of Cadmium in Chlorella pyrenidosa. Env. Research 14:401-413.

Haryoto dan Agustono W. 2004. Kinetika Bioakumulasi Logam Berat Kadmium oleh Fitoplankton Chlorella sp Lingkungan Perairan Laut. Jurnal Penelitian Sains \& Teknologi vol. 5 no.2 : 89-103

Imani, S, S.Rezael-Zarchi, A.M. Zand dan H.B Abarg.Hashemi, H. Boma, A. Javid, A.M. Zand dan H.B. Abarghouei. 2011. Hg, Cd and $\mathrm{Pb}$ Heavy Metal Bioremidiation by Dunaliella Alga. Journal of Medicinal Plants Research. Vol. 5 (13) pp. 2775-2780. http:/www.academicjournals.org/JMPR

Inthorn, D., N Sidtitoon, S.Silapanuntakul dan A. Incharoensakdi. 2002. Sorption Of Mercury, Cadmium And Lead By Microalgae. Science Asia 28: 253-261

Kadirvelu,K., K.Thamaraiselvi, C. Namasivayam. 2001. Removal of Heavy Metals from Industrial Wastewaters by Adsorption onto Activated Carbon Prepared from an Agricultural Solid Waste. Biorsour. Technol., 76. Pp.63-65.

Kusrinah. 2001. Penurunan Konsentrasi Logam Berat Kadmium (Cd) Air Laut Oleh Chlorella Sp Pada Skala Laboratorium. [Skripsi]. Jurusan Biologi. Fakultas Matematika dan Ilmu Pengetahuan alam. Universitas Diponegoro. Semarang

Leyva, R.R., J.R.R. Mendez, J .M.Barron, L.F. Rubio, R.M.G. Coronado. 1997. Adsorption of Cadmium (II) from Aqueous Solution onto Activated Carbon. Water Sci.Technol.35:205-211

Liljas, A. 1972. Crystal Structure of Human Carbonic Anhydrase. C. Nature New Biol $235: 131-137$. 
Lim,S.L， W.L.Chu， S.M.Phang. 2010. Use Chlorella vulgaris for Bioremediation of Textile Wastewater. Biosource Technology 101 , 73147322.doi:10.1016/biotech.2010.04.092

Mallick, N., and L.C. Rai. 1993. Influence of Culture Density, $\mathrm{pH}$, Organic Acid and Divalent Cations on The Removal of Nutrients and Metals by immobilized Anabaena doliolum and Chlorella vulgaris . World Journal of Microbiol \& Biotech.9 : 196 - 201

Muthukumaran, M.,V.V. Subramanian dan V. Sivasubramanian.2005.Utilization of algal Biomass For Colour Removal, pH Correction and Sludge reduction in Dyeing Effluent. Sustainable Utilization of Tropical Plant Biomass : 127-130

Olguin , E.J. 2003. Phycoremediation : Key Issues for Cost ewffective Nutrient Removal Processes. Biotechnol Adv. 22(1-2) : 81-90

Peraturan Menteri Negara Lingkungan Hidup nomor 03 Tahun 2010 Tentang Baku Mutu Air Limbah Bagi Kawasan Industri. 18 januari 2010 http://www.google.com/url?sa=t\&rct=j\&q= \&esrc $=$ s\&source $=$ web \&cd $=1 \&$ ved $=0$ CCYQ FjAA\&url=http\%3A\%2F\%2Fjdih.menlh.go. id\%2Fpdf\% diakses 3 Mei 2012

Phukan, M.M., R. S, Chutia, B.K. Konwar, R. Kataki. 2011. Microalgae Chlorella as A Potential Bio-Energy Feedstock. Applied Energy

http://www.elsevier.com/locate/apenergy diakses 12 Mei 2013

Prabowo, Danang A. 2009. Optimasi Pengembangan Media untuk Pertumbuhan Chlorella sp Pada Skala Laboratorium. Skripsi. Program Studi Ilmu dan Teknologi Kelautan Fakultas Perikanan dan Ilmu Kelautan, IPB

Prasad, M.N.V, K.I. Drej, A. Skawinska dan K. Stralka. 1998. Toxicity of Cadmium and Copper in Chlamydomonas reinhardtii wildtype (WT2137) and Cell Wall Deficient
Mutant Strain (CW15). Bull. Environ. Contam. Toxicol., 60 : 306-311

Rehman, A. dan A.R.Shakoori. 2003. Isolation, Growth, Metal Tolerance and Metal Uptake of The Green Alga, Chlamydomonas (Chlorophyta) and Its Role in Bioremediation of Heavy Metals. Pakistan J Zool., 35 : 337 - 341

Sanusi, H.S. 2006. Kimia Laut, Proses Fisik Kimia dan Interaksinya di Lingkungan. Departemen Ilmu dan Kelautan. Fakultas Perikanan dan Ilmu Kelautan. IPB. Bogor 188 hal

Sekabira, K., H.O. Origa, T.A. Basamba, G. Mutumba, E. Kakudidi. 2011. Apllication of Algae in Biomonitoring and Phytoextraxtion of Heavy Metals Contamination in Urban Stream Water. Int. J. Environ.Sci.Tech. 8(1) : $115-128$

Slamet, J.S. 1996. Kesehatan Lingkungan. Gadjah Mada University Press. Yogyakarta : 35 hal

Srihati dan Carolina. 1995. Kualitas Algae bersel tunggal Chlorella sp. Pada Berbagai Media. Seminar Ilmiah Hasil Penelitian dan Pengembangan Bidang Fisika Terapan.

Soeprobowati, T.R. dan R. Hariyati. 2012. The Potensial Used of Microalgae for Heavy Metals Remediation. Proceeding iSNPiNSA. Diponegoro University. Semarang

Syahputra, B. 2008. Pemanfaatan Algae Chlorella pyrenoidosa untuk Menurunkan Tembaga (Cu) pada Industri Pelapisan Logam http://smk3ae.wordpress.com/2008/05/09/pe manfaatan-algae-chlorella-pyrenoidosauntuk-menurunkan-tembaga-cu-padaindustri-pelapisan-logam diakses 15 Desember 2011

Tortora, GJ. 2001. Microbiology an Introduction. $7^{\mathrm{TH}}$ ed. World Student Series. San Francisco. USA

Tunali, S.C., A. Abuk., T. Afkar. 2006. Removal of Lead and Copper ions from aqueous Solutions by Bacterial Strain Isolated from Soil. Chem.Eng.J. 115, 203-211 
BIOMA, Desember 2015

ISSN: 1410-8801

Vol. 16, No. 2, Hal. 102 - 113 